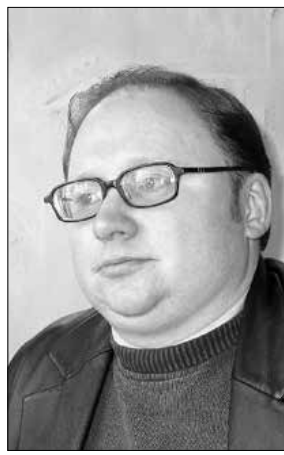

\title{
KŪRYBINĖS TECHNOLOGIJOS ANTIKOS FILOSOFIJOJE: KINIKŲ MOKYKLOS ATVEJIS
}

\author{
Creative Technologies in Antique Philosophy: The Case of Cynicism
}

\author{
SUMMARY
}

This article deals with application of creative technologies in Ancient Greek philosophy. The author concentrates on creative visualization technology used in ethics of classical cynicism. Namely, creative visualizations of the main ethical principles of cynicism - vicious surplus of pleasures and virtuous radical temperance - are scrutinized. The possible modern paraphrases of the above mentioned ancient visualizations are as well analyzed within the context of contemporary creative society. The article comes to conclusion that classical visualizations are not basically relevant to contemporary society. Yet, being prototypes of modern visualizations as well as broadening contexts and horizons of creative visualization itself, they retain significance for the analysis and deeper understanding of that society.

\section{SANTRAUKA}

Šiame straipsnyje nagrinėjamos kūrybinès technologijos, taikytos antikinėje filosofijoje. Straipsnio autorius susitelkia ties kūrybinès vizualizacijos technologija, atrandama klasikinio kinizmo etikoje. Straipsnyje analizuojami esminių šios etikos principų kūrybiniai įvaizdinimai ir jų galimos šiuolaikinès parafrazès. Prieinama prie išvados, kad klasikinės vizualizacijos iš esmės nebėra aktualios šiuolaikinės kūrybos visuomenės realijoms. Kita vertus, būdamos šiuolaikinių ìvaizdinimų provaizdžiais, o kartu ir išplèsdamos pačios kūrybinès vizualizacijos horizontus, jos išlaiko reikšmingumą šios visuomenès analizei.

\section{IVADAS}

Kūrybiškumo reiškinys būdingas visoms kultūroms, civilizacijoms, istorinèms epochoms. Kiekvienai jų būdingi specifiniai kūrybiškumo bruožai ir aspektai. Vis dèlto kūrybiškumas visada išlaiko keletą esminių savybių. Kaip 
pažymi ši fenomeną nagrinėjantys autoriai J. P. Guilfordas ${ }^{1}$, J. Howkinsas ${ }^{2}$, R. Florida ${ }^{3}$, P. Baltrènas, E. Baltrènaite $\dot{e}^{4}$, T. Kačerauskas ${ }^{5}$, J. Barevičiūtè ${ }^{6}$, A. Juzefovič ${ }^{7}$ ir kt., kūrybiškumui būdinga originalumas, individualumas, inovatyvumas, sklandumas (fluency), lankstumas, detalumas, jautrumas kūrybinei problemai ir $\mathrm{t}$. $\mathrm{t}$.

Kūrybiškumas kaip daugiamatis, daugiasluoksnis ir daugialypis fenomenas skleidžiasi ivvairiose srityse. Viena esminių jo raiškos erdvių - vaizduotès, vaizdijimo ir îvaizdinimo sritis. Šioje srityje svarbus vaidmuo tenka kūrybinei vizualizacijai, arba i̇vaizdinimui, kaip vienai esminių kūrybinių technologijų. Tiesa, pats terminas „kūrybinis įvaizdinimas" (creative visualization) dažniausiai vartojamas psichologijos moksle gana siaura prasme. Jis paprastai reiškia įvairias vaizduotès technikas kurti ir detaliai ivvaizdinti scenarijus, kuriuos būtų galima realizuoti (W. D. Wattlesas ${ }^{8}$, Sh. Gawain ${ }^{9}$ ). Tuo tarpu šiame straipsnyje „kūrybinès vizualizacijos" terminas bus vartojamas plačiausia reikšme - kaip kū- rybiškas regimo ir apčiuopiamo pavidalo suteikimas įvairioms idejoms, koncepcijoms, problemoms, įsitikinimams, abejonėms, klausimams ir t. $t$.

Nagrinejjant kūrybinį ivvaizdinimą, kaip ir bet kurią kitą kūrybiškumo apraišką ar technologiją, svarbu iš akių neišleisti istorinès perspektyvos. Šioji leidžia nustatyti idejini ir istorini konkrečios kūrybiškumo apraiškos pagrindą bei užtikrina gilesnę, platesnę ir nuodugnesnę jos interpretaciją. Šiame straipsnyje susitelkiama ties kūrybinès vizualizacijos technikomis ir apraiškomis antikinès Graikijos kinikų etikoje.

Ivairius kinikų etikos aspektus tyrè D. R. Dudley'us ${ }^{10}$, F. Sayre'as ${ }^{11}$, A. J. Malherbe'as $^{12}$, L. Navia ${ }^{13}$, W. Desmondas ${ }^{14}$ ir kt. Šiame straipsnyje nagrinèjamas antikinis kinizmas iš naujos ir mažai tyrinètos kūrybinès vizualizacijos perspektyvos. Analizuojama, kaip kinikai kūrybiškai įvaizdino 2 esminius savo etikos principus - ydingaji malonumų ratą ir dorybingaji radikalų saikingumą. Taip pat klausiama, kiek šios vizualizacijos yra aktualios šiuolaikinei visuomenei.

\section{YDINGASIS MALONUMŲ PERTEKLIUS IR JO IVAIZDINIMAI}

Filosofinè kinikų mokykla, ikurta Atènuose V a. pr. Kr. Antisteno ir Diogeno Sinopiečio, išgarsèjo globaliu maištu prieš antikinę civilizaciją ir jos moralę. Maišto priežastis gana paprasta. Kinikų isitikinimu, civilizacija naikinanti laimę ir sveikatą užtikrinančią saikingumo dorybę ir pakeičianti ją žmogaus prigimti griaunančiu malonumų pertekliaus vaikymusi.

Kodèl ši vaikymąsi kinikai laikè didžiausia žmonijos nelaime? Kodèl kiniz- mo tèvas Antistenas mėgdavo kartoti: „Man geriau išprotèti, nei mėgautis "15? Atsakymą pateikia vienas svarbiausių kinizmo etikos konstruktų - smagračio principas. Pasak jo, kuo daugiau malonumų patiriama, tuo daugiau jų geidžiama (ir netgi hic et nunc).

Kad neliktu grynąja teorija, šiam principui reikèjo ittikinamos vizualizacijos. Pirmiausia jis buvo konkretizuojamas per vergijos vaizdinic. Pasak kinikų, malonumų rate žmogus, pats to nejausdamas, 
po truputi praranda savo prigimtinę laisvę ir neišvengiamai tampa malonumų pertekliaus vergu. Jis nuolat medžioja malonumus, nuolat ju geidžia nebepajègdamas gyventi ju užribyje. Tačiau joks malonumu perteklius negali jo iki galo patenkinti, net pats intensyviausias mégavimasis nelaiduoja ramybės ir laimès.

Kita vertus, sukimąsi malonumų rate kinikai ìvaizdino kaip vandenligę. Malonumų medžiotoją jie prilygino nuo šios ligos kenčiančiam žmogui - ji nuolatos kankinąs nenumaldomas troškulys, ir kuo gausiau jis patenkinamas, tuo sparčiau auga ${ }^{16}$. Šis bendrasis vandenligès vaizdinys buvo individualizuotas konkrečiais vaizdiniais, arba apraiškomis: turtu, valdžia, šlove, seksualiniu pasitenkinimu ir t. t. Pasak kinikų, šių dalykų niekad nepakanka. Žmogaus niekada netenkina turimas turtas ar šlovè, nèra galo valdžios siekimui bei stiprinimui ir t. $t$.

Abi minètos ydingojo malonumų rato vizualizacijos akivaizdžiai yra kūrybinio pobūdžio. Pirmiausia jos buvo jautrios aktualiai antikinio pasaulio problemai - nuolatinei malonumų medžioklei. Antra, tai buvo nauji ir originalūs įvaizdinimai bendrajame klasikinès graikų kultūros kontekste. Antikinio pasaulio piliečiui malonumų gausa buvo vienas siekinių, ivaizdinamas pasiturinčiu žemišku gyvenimu ir nesibaigiančia pomirtine puota Eliziejaus laukuose. Tad malonumų perteklius nereiškė nei vergijos, nei ligos. Galiausiai abi vizualizacijos buvo išties detalios - kinikai pateikdavo išsamius malonumų sukeliamos vergijos ir ligos aprašymus.

\section{DORYBINGAS RADIKALUSIS SAIKINGUMAS IR JO VIZUALIZACIJOS}

Kinikų ìsitikinimu, žmogiškoji prigimtis civilizacijoje serga. Kad neištiktu mirtis, būtinas gydymas, o vienintelis efektyvus vaistas būtų grižimas prie prigimtinio saikingumo - žmogaus prigimties esminès savybės ir dorybės. Svarbu pažymèti, kad kinikai turèjo galvoje ne iprastą saikinguma, arba saiko visame kame jutimą. Jie kalbejjo apie radikalų saikingumą - maksimalų žmogiškųju poreikių apribojimą. Kalbant šiuolaikine kalba, toks saikingumo variantas būtų maksimalus vartojimo sumažinimas. Pasak kinikų, tik minimalus maisto, rūbų, avalynès, seksualinių malonumų ir kitų gèrybiu kiekis gali visiškai patenkinti žmogiškają prigimtị; suteikti savipakankamus ir i perteklių nevedančius malo- numus. Kita vertus, būtent minimalūs poreikiai yra būtiniausieji, jie gali būti patenkinami iš esmès visur ir visada. Tad minimalus poreikių skaičius apsaugo nuo ateities baimės ir suteikia sielos ramybès ir gero nusiteikimo būsena, kuri, kiniku issitikinimu, ir esanti ne kas kita kaip pati žmogiškoji laimè $\dot{1}^{17}$.

Taigi jei malonumų medžioklè buvo vizualizuojama vergo ir ligonio vaizdiniais, su saikingumu būta priešingai. Jis buvo interpretuojamas ir propaguojamas vaisto (pharmakon), sveikatos ir visiškos laimès vaizdiniais. Sveiko ir laimingo žmogaus vaizdiniai kartais netgi igydavo kosmopolitini matmeni, virsdami paveikslu Visatos piliečio, gebančio laisvai ir laimingai gyventi bet kurioje jos dalyje. 
Erdvinis - laikinis šio paveikslo universalumas buvo reprezentuojamas 2 būdais. Pirmiausia mitine praeitimi, tai yra vaizdais ir scenomis iš Aukso amžiaus žmonių gyvenimo. Antra, utopine ir mitologizuota dabartimi: tolimomis įsivaizduojamomis salomis ir kai kuriomis idealizuotomis barbaru gentimis ir valstybemis.

\section{MITINĖS PRAEITIES SAIKINGOJO GYVENIMO IVAIZDINIMAI}

Panagrinèkime šias vizualizacijas pradėdami nuo Aukso amžiaus paveikslo. Kinikai šį amžių aprašinëjo Hesiodo stiliumi - kaip visuotinio moralumo, laimès, taikos ir ramybės laikotarpì. Saikingiems to amžiaus žmonèms visiškai pakakdavę dosnios gamtos ir derlingos žemès dovanų. Tomis dienomis viešpatavusi visuotinè lygybė. Pasak kinikams simpatizavusio garsaus graiku satyriko ir skeptiko Lukiano, Aukso amžiuje "vergovès tiesiog nebuvo“18.

Deja, ši palaimingajij prigimtini būvi ilgainiui pakeitè pragaištingoji civilizacija. Ji paneigé prigimtinio saikingumo maksimą ir sunkiai bei ilgam sužalojo žmogiškąją prigimtį. Pasak kiniko Diogeno Sinopiečio, visi civilizuotų žmoniu išradimai ir gudrybès neatnešè žmonijai jokios naudos: „žmogaus sumanumas ir gebëjimas atrasti bei išrasti daugybę gyvenimo palengvinimu buvo visai nenaudingi vẻlesnèms kartoms, nes žmonès panaudoja savo protus ne narsai ar teisingumui skatinti, o vien malonumu siekti“19. Malonumu pertekliui tapus pagrindiniu žmonijos tikslu, prasidèjo kova dèl jo ir jo pasiekimo priemonių: turto, valdžios, šlovès, kilmingumo ir kt.
Šios kovos pasekmès - karai, turtinè bei teisinè nelygybè, vergovè.

O kada tai nutiko? Kaip jau minèta, kinikai prigimtinio saikingumo karaliavimą iliustravo Aukso amžiaus vizija. Tad visiškai suprantama, kad nelemtasis civilizacinis posūkis taip pat neišvengè mitinio i̇vaizdinimo - žmonijos nelaimiu priežastimi paskelbtas graiku taip gerbtas titanas Prometèjas. Priežastis paprasta - būtent jis padovanojęs žmonijai iš dievu pavogtą ugnį. Kraštutinio saikingumo siekusiems kinikams tai neatrodė joks žygdarbis. Priešingai, tai laikyta didžiausiu nusikaltimu, už kurį Prometèjas gavo tai, ko nusipelnè. Pasak Diogeno, „teisinga, kad Prometèjas buvo prikaltas prie uolos, o peslys išplěšdavo jo kepenis “20. Teisinga, nes dovanotoji ugnis žmonijai nedavusi nieko gera. Priešingai, ji buvo žmonių „išlepimo ir prabangos kilmé bei pradžia“21 - pirmasis žmonijos žingsnis, žengiamas ị civilizaciją ịtvirtinantị malonumų perteklių. Taigi kinikai įvaizdino prigimtinio saikingumo viešpatavimą ir ji nutraukusi civilizacini posūki originalia kūrybine mitu apie Aukso amžiu ir Prometèją sinteze.

\section{SAIKINGO GYVENIMO MITOLOGIZUOTOJE IR UTOPINĖJE DABARTYJE VIZUALIZACIJOS}

Čia iškyla labai svarbus klausimas: ar, kinikų manymu, minètas posūkis yra užbaigtas, negrąžinamas ir neatšaukiamas? Jokiu būdu! Kinikai saikingumo 
karalystės neužrakino mitinëje praeityje. Aukso amžius nebuvo vienintelè laisvo, sveiko, saikingo ir laimingo gyvenimo vizualizacija. Prigimtinio saikingumo teritorijos buvo braižomos ir utopineje ar bent jau mitologizuotoje dabartyje. Tai issivaizduojamos tolimos salos ir kai kurios barbaru gentys. Panagrinékime visas šias kūrybines vizualizacijas.

Kadaise globalaus Aukso amžiaus liekanas kinikai pirmiausia atrado kai kuriose barbaru gentyse - persu, skitu ir pan. Šios gentys dar nepraradusios pirmapradžio santykio su gamta ir prigimtimi. Jos praktikuoja asketišką, tiek sielą, tiek kūną užgrūdinantį gyvenimo būdą tikrą gerosios praktikos pavyzdi išlepusiems ir ydu sugadintiems graikams bei daugeliui barbaru.

Šio asketiško gyvenimo reprezentatyviausiomis personifikacijomis kinikai laikè persų karalių Kirą ir legendinį skitų išminčių Anacharsį. Štai kinikų mokyklos ỉkūrèjas Antistenas lygino Kirą su mitiniu graiku herojumi Herakliu dorybingumo, saikingumo, ištvermingumo, tvirtumo, darbštumo etalonu ${ }^{22}$. Minètomis dorybėmis garsëjęs ir Anacharsis. Pasak nežinomo kinikų filosofo, Anacharsis šitaip trumpai pristatęs savo gyvenimo būdą: „,Mano drabužiai - plona skitiška skraistė, mano batai - stora mano paties pėdų oda, mano lova - žemé, mano maisto pagardas - badas, ir aš gyvenu pienu, sūriu ir mèsa. ${ }^{.23}{ }^{2}{ }_{\mathfrak{i}}$ saikingą maistą skitams teikianti derlinga žemè ir gausios galviju bandos. Tai bendra visų skitu nuosavybè - Anacharsio teigimu, „visi mes valdome visą že$\mathrm{meq}^{\prime \prime 24}$. Esant bendrai nuosavybei, skitu valdose nekariaujama dèl turto. Skitu taip pat nepuola išorès priešai bijodami jų santarvès, ištvermès ir narsos: „Mums ginklų reikia ne puolimui, o vien gynybai, jei iškyla tokia būtinybè. Tačiau tokios būtinybės iki šiol nèra buvę. Juk mes stotume prieš tuos, kurie mus pultų ir kaip karius, ir kaip [galimus] karo trofejus. O toks trofejjus būtu mielas nedaugeliui. “25

Idealizuotos ir mitologizuotos barbaru gentys nebuvo vieninteliai mitinès erdvès arealai, kuriuose kinikų kūrybinè vaizduotė vizualizavo prigimtinio moralumo ir saikingumo viešpatavimą. Tokiu arealų ieškota ir niekieno dar neatrastose įsivaizduojamose tolimose salose. Jas galima laikyti tam tikrais Tomo Moro Utopijos salos prototipais. Puikus pavyzdys - sala Elgetos krepšys (Пepa), aprašyta kiniko Krateto to paties pavadinimo poemoje. Svarbu pažymèti, kad elgetavimas buvo dažno kiniko gyvenimo būdo dalis, o pats elgetos krepšys kiniku filosofijoje simbolizavo radikalų saikingumą. Būtent jis ir viešpatauja Krateto saloje. Jos gyventojai tenkinasi vandeniu, figomis, česnakais, kmynais ir kitu paprastu derlingos žemès teikiamu maistu, kurio visiems pakanka. Ir apskritai malonumu perteklius čia nepageidaujamas - „čia neiplauks nei kvailys, nei velteddis, / nei apsirijèlis ar kūniško geidulio vergas “26. Malonumu pertekliui nesant siekiniu, nėra prasmès kariauti dèl jo pasiekimo priemonių: „vyrai čia viens su kitu nekovoja, / nei griebias ginklu pinigu ar garbès įsigeidę ${ }^{\text {“27 }}$.

Minètos radikalaus saikingumo vizualizacijos yra akivaizdžiai kūrybinio pobūdžio. Pirmiausia jos atspindejo aktualią antikinès civilizacijos problemą nuolatinę malonumų medžioklę. Iš esmès jos ir buvo ne kas kita kaip reakcijos i šią problemą, siūlančios tam tikrus jos sprendimo būdus. Antra, tai buvo naujos 
ir originalios vizualizacijos. Klasikinio pasaulio piliečiui kraštutinis saikingumas nereiškè nei vaisto socialinio pobūdžio ligoms gydyti, nei laimès įrankio. Toks saikingumas veikiau laikytas keistuolių, marginalų, religinę ezoteriką praktikuojančiu žmonių ar savo padèti bandančiu pateisinti varguolių reikalu. O dèl praeitin nugrimzdusio Aukso amžiaus ir jo dar nepraradusių tolimųju "dabarties" salu, visa tai antikinè literatūra paprastai i̇vaizdindavo ne kaip radikalaus saikingumo karalystes, o kaip tam tikrus visuotinès gerovès arealus, kuriuose malonumų perteklius pasiekiamas be jokiu pastangu ir triūso. $\mathrm{Na}$, o barbarai paprastai laikyti necivilizuotomis būtybėmis, labai artimomis saikingumo nepažistančiam laukinių gyvūnu pasauliui, neturinčiam jokio supratimo apie žmogiškają laisvę ir laimę bei panirusiam i̇ nesibaigiančių kovų ir žudynių ratą. Galiausiai anksčiau minètos vizualizacijos pasižymèjo kūrybiškumui reikalingu detalumu - kinikai išsamiai aprašè saikingaji Aukso amžiaus žmonių, tolimujuc salų gyventojų ir rinktinių barbaru gyvenimą.

\section{KINIKŲ KÜRYBINĖS VIZUALIZACIJOS IR ŠIUOLAIKINĖ VISUOMENÉ}

Malonumų medžioklè nesibaigè su antikine kultūra. Šiuolaikinejje vartotoju visuomeneje ji dar intensyvesnè ir įvairiapusiškesnè. Modernus mokslas ir technologijos pavertė malonumus lengvai prieinamus vartojimui. Kita vertus, nuolatinis vartojimas, itin spartus gyvenimo tempas, noras būti, turèti, daryti daugiau ir greičiau sekina šiuolaikini žmogų. Maža to, šie veiksniai neleidžia pasitenkinti paprasčiausiais dalykais, jausti gyvenimo džiaugsma, patirti akimirkos groži; palaiko nesibaigiantį nerimą ir baimę nespèti, nepavartoti, neturèti. Tad šiuolaikinè malonumų medžioklè galètų būti vizualizuota vaizdiniu žmogaus, gyvenančio niekada nesibaigiančiame skubejjime. Jis skuba pabaigti savo gausius darbus, kad galètų pasimėgauti taip trokštamais malonumais, kurie gana lengvai pasiekiami, bet gausa nenusileidžia darbams. Vis dèlto jam niekaip nepavyksta nei užbaigti darbu, nei visiškai atsiduoti malonumams, kurių kiekybė auga kartu su inten- syvesne paklausa. Šis žmogus tiesiog neturi laiko abiem anksčiau minètiems tikslams. Jam belieka užsidaryti nesibaigiančiame nebaigtų darbų ir iki galo nepatirtu malonumu rate, kartojant roko grupès „The Rolling Stones“ populiarios dainos „Satisfaction“ žodžius: „Negaliu patirti pasitenkinimo“...

Šią šiuolaikinès malonumų medžioklès vizualizaciją galime palyginti su kiniku pateiktais ivvaizdinimais - nesibaigiančiu vergystès ratu ir konkrečia liga vandenlige. Šiuolaikinis nesibaigiančios skubos rate ikkalinto žmogaus vaizdinys taip pat nurodo tam tikrą vergovę ir ligą. Tiksliau kalbant, toks nesibaigiantis skubejjimas jau pats savaime yra tam tikra vergovè ir liga. Todèl ši laikmeti įreminantis gausiu pusiau baigtu darbų ir iki galo nepatirtu malonumų ratas - tai tam tikra vergovę ir nesveikatą lemiančio klasikinio malonumų pertekliaus smagračio variacija. Tiesa, antikinis ir šiuolaikinis tiek vergovès, tiek ligos variantai 
yra skirtingi, todèl klasikinès vizualizacijos nelabai tinka šiuolaikinès visuomenès bèdoms reprezentuoti. Vis dèlto klasikinis ịvaizdinimas išlaiko šiuolaikinių vizualizaciju prototipo statusą - čia ir glūdi minètojo i̇vaizdinimo svarba šiuolaikinei situacijai.

O kas joje galètų bent jau retkarčiais sustabdyti anksčiau minètą nesibaigiančios skubos ratą ar bent jau pristabdyti, sulètinti? Viena galimu priemoniu - pasirinkti saikingesni gyvenimo būda, kitaip sakant, sumažinti vartojimą. Tiesa, šiuolaikinis žmogus ipratęs gyventi komfortabiliai, daug noreti, turèti ir vartoti. Bet juk galima tiesiog pabandyti gyventi saikingiau, atsisakyti to, kas nebūtina. Tokia gyvenimo strategija - minimalus saikingumas - bent minimaliai pagerintu gyvenimo kokybę, dovanotų daugiau sveikatos, ramybès, pastovumo ir elementaraus džiaugsmo. Tad šiuolaikinei visuomenei reikalingas ne radikalusis, bet švelnusis, arba nuosaikusis, saikingumas - saiko visame kame jutimas.

Kaip jau minèta, šiuolaikinė malonumų medžioklè gali būti iliustruota nuolat skubančio žmogaus gyvenimo vaizdiniu. Švelnusis saikingumas savo ruožtu gali būti vizualizuojamas vaistų nuo šio skubejimo vaizdiniu, taip pat ir paveikslu žmogaus, kuris pagal lotynu patarlę „Festina lente ${ }^{\prime 28}$ skuba pakankamai lètai. Ar bent jau trumpam pristabdo, ar netgi sustabdo skubejjima, kad išeitu iš minètojo rato pasimégauti gamtos gro- žybėmis, paskanauti paprasto maisto, pasikalbèti su draugais, paskaityti iqdomią knyga, nueiti į teatrą, kiną etc.

Šią šiuolaikinę nuosaikaus saikingumo vizualizaciją idomu palyginti su kiniku pateiktu klasikiniu radikalaus saikingumo ivvaizdinimu. Pastarasis saikingumą vizualizavo 2 būdais: a) vaistų nuo nesibaigiančios malonumų medžioklès vaizdiniu; b) šiu vaistų vartojimo rezultatu - pastovios sveikatos, laimès ir laisvès būsenos - vaizdiniais. Modernioji saikingumo vizualizacija taip pat apima vaistu vaizdini. Tai vaistai nuo nesibaigiančios skubos rato. Kita vertus, šiuolaikinè vizualizacija įtraukia ir šių vaistu vartojimo efekto vaizdini - skubos rato sulètinimą ar bent jau nutraukimą trumpam laikui. Šis skubejjimo sulètinimas ar sustabdymas taip pat suteikia tam tikrą sveikatos, laisvès ir laimès būseną. Vis dèlto, skirtingai nuo antikiniu prototipu, ši sveikata, laisvè ir laimè yra laikinos ir fragmentinès, o ne pastovios ir vientisos. Taigi šiuolaikinio saikingumo vizualizacija - tai tam tikra radikalaus saikingumo klasikinio ivvaizdinimo variacija. Tiesa, būdama skirtingos saikingumo rūšies ivaizdinimu, klasikine vizualizacija iš esmės nẻra tinkama šiuolaikinei visuomenei. Tačiau ji nepraranda reikšmingumo kaip šiuolaikiniu i̇vaizdinimų provaizdis, be kita ko, siūlantis alternatyvius saikingumo scenarijus statistiniam vidurkiui nepaklūstantiems visuomenès elementams.

\section{UŽSKLANDA}

XXI a. Vakarų visuomenė dažnai įvardijama kaip kūrybos visuomenė, turinti savo esmines charakteristikas, kūrèjų grupes, kūrybiškumą matuojančius indeksus ir t. t. Vis dèlto kūrybiškumas, jo irankiai, metodikos ir technologijos egzis- 
tuoja nuo neatmenamų žmonijos laikų. Tų technologijų turinys, forma, subjektai ir adresatai priklauso nuo konkrečios istorinès epochos, kultūros, civilizacijos etc. Šiame kontekste svarbi istorinè kūrybiškumo formų, metodu, technologijų analizè. Ją būtų netikslu laikyti vien kūrybiškumo archeologija, ieškančia reikšmingu faktų kūrybiškumo kapinynuose. Tai veikiau istorinė kūrybiškumo komparatyvistika, ne tik atskleidžianti ir lyginanti ivvairių epochų kūrybiškumo formų ir

\section{Literatūra ir nuorodos}

1 Joy Paul Guilford, Analysis of Intelligence. New York: McGraw-Hill Education. 1971.

2 John Howkins, Creative Economy: How People Make Money from Ideas. London: Penguin Books, 2001.

3 Richard Florida, The Rise of Creative Class: And How It's Transforming Work, Leisure, Community and Everyday Life. New York: Basic Books, 2002.

4 Pranas Baltrènas et al., Social Environment of Creativity. Filosofija. Sociologija, 26(1), 2015, p. 46-54.

5 Tomas Kačerauskas, Technologies in Creative Economy and Creative Society. Technological and Economic Development of Economy, 21(4), 2015, p. 240-252.

6 Jovilè Barevičiūtè, Pagrindiniai kūrybiškumo ir kūrybingumo aspektai šiuolaikiniuose humanitariniuose bei socialiniuose moksluose. Filosofija. Sociologija, 25(1), 2014, p. 19-28.

7 Agnieška Juzefovič, Creative Interactions between Word and Image in Modern Visual Culture. Limes: Borderland Studies, 6(2), 2014, p. 121131.

8 Wallace Delois Wattles, The Science of Getting Rich. Oxford: Infinite Ideas, 2012.

9 Shakhti Gawain, Creative Visualization: Use the Power of Your Imagination to Create What You Want in Your Life. Novato, California: New World Library, Nataraj Publishing, 2002.

10 Donald R. Dudley, History of Cynicism. From Diogenes to the 6th Century A.D. London: Methuen \& Co, 1937.

11 Farrand Sayre, The Greek Cynics. Baltimore: J. H. Furst Company, 1948.

12 Abraham J. Malherbe (Ed.), The Cynic Epistles: technologijų esminius požymius, bet ir atverianti alternatyvius kūrybiškumo kontekstus ir horizontus šiuolaikinei kūrybos visuomenei. Juk, kaip teigia žinoma patarlè, nauja neretai būna gerai pamiršta sena. Galime prisiminti kad ir XIX a. modernios formaliosios logikos kūrèjus, netikètai atradusius, kad iki tol menkai vertinta viduramžių scholastinè logika jau buvo pasiūliusi jiems iškilusių problemų sprendimo būdus, tiesa, formuluotus kitokia kalba, pavyzdžiais ir metodais.
A Study Edition. Missoula, Montana: Society of Biblical Literature, 1977.

13 Lius Navia, Classical Cynicism: a Critical Study. London: Greenwood Press, 1996.

14 William Desmond, Cynics. Ancient Philosophies. Stocksfield: Acumen Publishing Limited, 2008.

15 Diogenes Laertius, Lives of the Eminent Philosophers. Vol. II. Translated by R. D. Hicks. Cambridge, Massachusetts: Harvard University Press, 1925, p. 5.

16 Joannes Stobaeus, Florilegium. Volumen I. Oxonii: E typographeo clarendoniano, 1822, p. 295.

17 Joannes Stobaeus, Florilegium. Volumen III. Lipsiae: In bibliopolio Kuehniano, 1824, p. 294.

18 Lucian of Samosata. Saturnalia. The works of Lucian of Samosata. Volume IV. Translated by H. W. Fowler and F. G. Fowler. Oxford: The Clarendon Press, 1905, p. 111.

19 Dio Chrysostom. Discourses I-XI. Translated by J. W. Cohoon. Cambridge, Massachusetts: Harward University Press, 1932, p. 266.

20 Ten pat, p. 267.

21 Ten pat, p. 265.

22 Diogenes Laertius, p. 5.

23 Marcus Tullius Cicero, Tusculanae Disputationes. Volume V. Cambridge, Massachusetts: Harvard University Press, 1927, p. 516.

24 Abraham J. Malherbe (d.), The Cynic Epistles: A Study Edition. Missoula, Montana: Society of Biblical Literature, 1977, p. 49.

25 Ten pat, p. 51.

26 Diogenes Laertius, p. 89.

27 Ten pat.

28 Lot. - „skubèk lètai“. 